\title{
Avifauna of North-western Peru Biosphere Reserve and its environs
}

\author{
A. GAYLON COOK
}

\begin{abstract}
Summary
The avifauna of the environs of North-western Peru Biosphere Reserve (NPBR) is herein catalogued. This reserve embraces the largest example of protected Neotropical Pacific xeric forests, a habitat complex much scarcer than rainforests. NPBR is very important conservationally because much of the adjoining dry-forest region of south-western Ecuador has been denuded. Exact locality records and their specific literature sources are furnished for North American migrants and those species which have inhabited the vicinity of NPBR but have not been reported there by the authors of reference books that address avian geography. For each tabulated avian species, the earliest attribution or one of the earliest attributions for a specific record of that taxon in the environs of NPBR is provided. Also, 16 species that are threatened, or are endemic to a short strip of extreme south-western Ecuador and north-western Peru, are noted.
\end{abstract}

La avifauna del entorno de la Reserva de la Biósfera del Nor-Oeste Peruano (RBNO) es registrado aquí. Esta reserva abarca el ejemplo más grande de bosques secos Neotropicales Pacíficos que están protegidos. Este complejo único de hábitats es mucho más escaso que selvas húmedas. La RBNO es muy importante de la punta de vista de conservación porque mucha de la región de los bosques secos colindantes en Ecuador sudoeste ha sido talada. Este escrito facilita registros exactos de localidad y sus fuentes bibliográficas específicas tocante a las especies emigrantes norteamericanas y aquellas aves que han habitado en las inmediaciones de la RBNO pero cuya existencia allá no se ha asentado por los autores de libros ornitológicos de consulta que tratan sobre la geografía avícola. Por cada especie de ave tabulada, es proporcionada la atribución más antigua o una de las atribuciones más antiguas para un registro específico de élla en el entorno de la RBNO. También, son indicadas en el apéndice las 16 especies que están amenazadas con extinción o que son endémicas a una faja terrestre corta de Ecuador sudoeste extremo y el Perú noroeste extremo.

\section{Description of North-western Peru Biosphere Reserve and its resources}

The North-western Peru Biosphere Reserve (NPBR) - Reserva de la Biósfera del Nor-Oeste Peruano (RBNO) - was ratified by the International Committee of the Man and the Biosphere Programme of the United Nations Educational, Scientific, and Cultural Organization (UNESCO) on I March 1977 (Anon. 1988). This Peruvian reserve comprises 234,374 ha in the hooked digitation of extreme north-western Peru (Figure 1). Situated in the political departments of Tumbes and Piura, the coterminous NPBR $\left(3^{\circ} 41^{\prime}\right.$ to $4^{\circ} 26^{\prime} \mathrm{S} 80^{\circ} \mathrm{O} 8^{\prime}$ to $\left.80^{\circ} 57^{\prime} \mathrm{W}\right)$ encompasses the Reserved Zone of Tumbes (Zona Reservada de Tumbes; formerly 
Tumbes National Forest) on the north with an area of 75,102 ha, Hills of Amotape National Park (Parque Nacional Cerros de Amotape) in the centre with an area of 91,300 ha, and El Angolo Hunting Reserve (Coto de Caza El Angolo) on the south with an area of 65,000 ha (sites 1-3, Figure 1). Mangroves of Tumbes National Sanctuary (Santuario Nacional Manglares de Tumbes; $3^{\circ} 24^{\prime}$ to $3^{\circ} 27^{\prime} \mathrm{S} 80^{\circ} 13^{\prime}$ to $80^{\circ} 19^{\prime} \mathrm{W}$ ), which embraces 2,972 ha on the coast of the Pacific Ocean (site 4, Figure 1), has recently become a part of NPBR.

NPBR is the largest protected example of Neotropical Pacific dry forests. Such forests in adjoining Ecuador have largely been cleared. The reserve's varied topography includes mangroves, desert scrub, and multiple dry-forest communities in the Brea chain of low (largely $<1,400 \mathrm{~m}$ ) mountains (Anon. 1988). Mean annual precipitation ranges from 125 to 2,000 mm. Averaging $800 \mathrm{~mm}$ in Hills of Amotape National Park, rainfall is lower in El Angolo Hunting Reserve and Mangroves of Tumbes National Sanctuary, but higher in the Reserved Zone of Tumbes. About $85 \%$ of it falls from January to April (Anon. 1988).

The exploitation of natural resources in NPBR needs to be ameliorated. Of the live birds that are captured in Peru for future sale, c.70\% are Grey-cheeked Parakeets Brotogeris pyrrhopterus and 25\% are Red-masked Parakeets Aratinga erythrogenys (Anon. 1988). In 1987, seizures of psittacids equalled 5,700 about Tutumo Hill and 9,000 about El Chailo (Figure 1). In 1974, Peru established a moratorium against the felling of healthy trees in the departments of Tumbes and Piura (Balmaceda 1986). Despite the prohibition, much surreptitious logging has occurred near roads, particularly near Rica Playa and Matapalo (Figure 1) (Anon. 1988). Several logging roads bisect the access road bordering the Reserved Zone of Tumbes and La Angostura Creek. There is a threat that illegal logging could extend into the zone.

Thirteen species of threatened birds have been reported in the vicinity of NPBR (Figure 1) including three that are also endemic to a stretch of south-western Ecuador and north-western Peru (see Appendix). Collar et al. (1992) give the locality records for these taxa. One of these species is the White-winged Guan Penelope albipennis, which J. Stolzmann declared had been common in the Tumbes vicinity around 1846 , but which owing to persecution had retreated to mangroves (Taczanowski 1886: 271-273). In 1876, the species could always be found on Condesa Islet in Tumbes River delta. A male specimen was collected by Stolzmann at Santa Lucía (Taczanowski $1877 \mathrm{~b}$ ) on 18 December 1876. A female specimen from Antonio Raimondi's collection (Taczanowski 1886: 271-273) was taken at Pabur Hacienda, to the east (Vaurie 1972) or south-east (de Macedo-Ruiz 1979) of Piura city (Figure 1). During the next century, the White-winged Guan was not detected but then, in September 1977 , it was rediscovered at $5^{\circ} 35^{\prime} \mathrm{S} 79^{\circ} 48^{\prime} \mathrm{W}$ (de Macedo-Ruiz 1979) in southern Piura Department (see Peñaherrera del Aguila 1989: 229, 273). A more recent record of the White-winged Guan at 5 31'S (Collar et al. 1992: 115-119) was actually also in Piura Department. Peñaherrera del Aguila (1989) showed the tip of the northernmost projection of Lambayeque Department to be at $5^{\circ} 32.2^{\prime} \mathrm{S}$ (p.229) or $5^{\circ} 32.0^{\prime} \mathrm{S}$ (p.273). In this century, the species has not been confirmed in the area shown in Figure 1. 


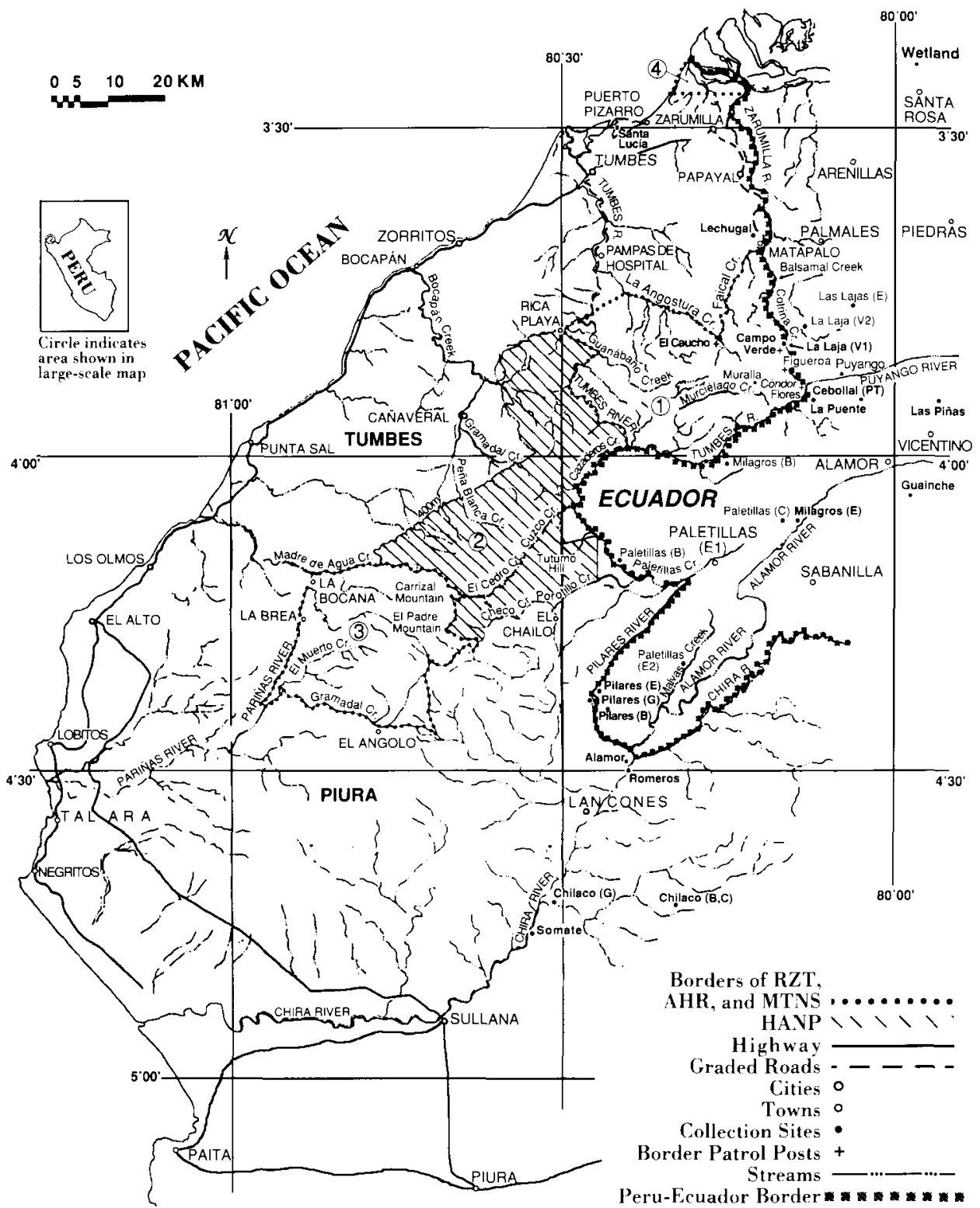

Figure 1. Map of the environs of North-western Peru Biosphere Reserve including (1) the Reserved Zone of Tumbes (RZT), (2) Hills of Amotape National Park (HANP), (3) El Angolo Hunting Reserve (AHR), and (4) Mangroves of Tumbes National Sanctuary (MTNS). The symbols following names of avian collection sites (all with elevations $\leqslant 1,450 \mathrm{~m}$ ) and the maps or documents to which they refer are E, E1 and E2, Repriblica del Ecuador, Mapa Geográfico (1979); G, American Geographical Society's Piura S. B-17 map (1948); B, A. Brisesmeister's imprecise 1921 map (Chapman 1926, plate 30); C, Chapman's (1926) crude plate 3; V1 and V2, Vaurie (1972); and PT, Paynter and Traylor (1977). Modified from maps of Parques Nacionales-Perú. 


\section{Objectives}

It is hoped that the cataloguing of the avifauna of the environs of NPBR will attract professional and amateur ornithologists there, and that the augmented interest in the reserve will enhance its conservation. The avifaunal list that has been developed uses a symbol to show those avian species that have occurred in the immediate Ecuadorian surroundings of NPBR but not in extreme north-western Peru. Perhaps some people will be inspired to search for these species in NPBR (and in Peru).

Also, it is my aim to contribute to Neotropical avian geography. Omitted records (not all are recent), and errors in ornithological reference books that treat the ranges of taxa that inhabit the environs of NPBR, are delineated so that the readers of these publications will be aware of them, but also in the anticipation that the authors of future volumes addressing South American avian distributions will use the data provided.

\section{Former avian collection sites}

Several avian collection sites in the vicinity of NPBR have been assigned by ornithologists to the wrong country, department or province. This confusion has partially resulted from ornithologists earlier in this century using imprecise maps. Another source of misunderstanding is the duplication of names for towns that exist (or existed) across a border from each other, or in the same department or province. The marked loop in the Ecuador/Peru frontier a short distance south-east of south-eastern Hills of Amotape National Park (Figure 1) has also probably led to errors in ascribing collection sites to a specific country.

Carriker's (1935, Bond 1945) La Laja (V1) collection site $\left(3^{\circ} 50^{\prime} \mathrm{S} 80^{\circ} 10^{\prime} \mathrm{W}\right)$, located along Zarumilla River and the border of Ecuador and Peru (Figure 1 ), is not situated in northern Piura Department but rather in Tumbes Department, Peru (Vaurie 1972). La Laja (V1), as well as Laja (V2) north-eastward in Ecuador, was derived from Vaurie's (1972) gazetteer since the American Geographical Society's Hispanic America topographic map entitled Quito: South (S.) A-17 (1938), which Vaurie used to examine the part of Figure $I$ that is north of $4^{\circ} \mathrm{S}$, is out of print. Figure $I$ gives reference sources for the localities of avian collection shown in that map.

A perusal of the itinerary of Harry Watkins (Chapman 1926: 77-79), who collected birds within the boraier area of Peru and Ecuador in 1919, aids in the elucidation of several ambiguous collection sites. Watkins followed an indirect route from Paita, Piura Department, Peru, to Tumbes, Peru (Figure 1).

He journeyed from Paita to Sullana and thence $61 \mathrm{~km}$ along Chira River to Lamor (=Alamor, Peru; see Zimmer 1950: 4). Then he walked the short stretch of Alamor River between Chira River and Pilares River, and travelled up Pilares River to the town of Pilares (Figure 1). Some distance south of Pilares on the 1979 Ecuadorian map, República del Ecuador: Mapa Geográfico (REMG), the Ecuador-Peru border veers westward I km from Pilares River; Pilares (E) (Figure 1) sits immediately east of the river, well inside Ecuador on that map. Pilares (B) (Figure 1) lies even farther east (Chapman 1926, plate 30). However, Peñaherrera del Aguila (1989: 229) placed Hito Papayo Pilares (= Pilares) in the 
middle of Pilares River and the international border. According to the Operational Navigational Chart (ONC) M-25 (1990) of the Defense Mapping Agency Aerospace Center (St Louis, Missouri, U.S.A.), Pilares lies largely west of Pilares River. The American Geographical Society's Piura Map S. B-17 shows Pilares (G) (Figure I) on the west side of Pilares River within Peru. Thus, avian locality labels of "Pilares, Peru" may indeed be valid.

From the village of Pilares, Watkins followed Pilares River $29 \mathrm{~km}$ upstream to its source (at the north-west border of the Ecuadorian protrusion into Peru; Figure 1). Then he proceeded to his next collection site of Paletillas [Ex] (Figure 1; nearly agreeing with Paynter and Traylor's 1977 coordinates which place it only $1.5 \mathrm{~km}$ farther south) situated beside a small stream (Paletillas Creek) in the Tumbes River watershed. From around 1921 to 1977 (see Paynter and Traylor 1977), Chapman and other authors erroneously placed this camp and Milagros (see below) in Piura Department, Peru. Vaurie (1972) mistakenly noted that on the American Geographical Society's Piura S. B-17 map, Paletillas is located at $4^{\circ} 15^{\prime} \mathrm{S} 80^{\circ} 25^{\prime} \mathrm{W}$ in Piura Department. Paletillas does not occur anywhere in western Piura Department, Peru, or Loja Province, Ecuador, on the latest version (1948) of map S. B-17. After leaving Paletillas, Watkins tortuously hiked $29 \mathrm{~km}$ to the base of Cerro Verde and an additional $16 \mathrm{~km}$ to the Milagros (E) collection site (Figure 1).

From Milagros (E), Watkins presumably proceeded north-eastward along Alamor River, traversing it and its tributaries many times. His log states that he crossed "innumerable quebradas". After a $39-\mathrm{km}$ trek, Watkins reached a camp near Alamor, Ecuador, that was located on the highest ridge between Alamor River and Tumbes (= Puyango) River (Figure 1) (Chapman 1926: 78, 703). The elevation (1,326 m) of the Alamor camp (Chapman 1926: 78 , plate 17 ) suggests that it was situated a few kilometres east or north-east of the city of Alamor. An apparent typographical error in the appendix of Chapman's (1926: 703) monograph, noting the Alamor camp elevation as 4,550 feet $(1,387 \mathrm{~m})$, was repeated by Zimmer (1950). Finally, Watkins journeyed to Puyango, and thence to Tumbes via Lajilla (south of Figueroa) (Figure 1).

Because land elevations significantly influence avian ranges, the elevations of the former localities of avian collection shown in Figure 1 are indicated below. Elevations were provided by Wiedenfeld et al. (1985) for El Caucho and Campo Verde; by Peñaherrera del Aguila (1989) for Tumbes, Zorritos, Talara, Sullana, Piura and Paita; by Paynter and Traylor (1977) for Palmales, Arenillas and Santa Rosa; by Best et al. (1992: 148) for Alamor (in part) and Vicentino; by Bloch et al. (1991) for the "wetland"; and by Chapman (1926) for many sites. Elevations of a few collection localities were estimated using the lines of topography on REMG, map S. B-17, or map ONC M-25. The elevation of El Angolo was reported to be $700 \mathrm{~m}$ by Schulenberg and Parker (1981), and shown to be 500$700 \mathrm{~m}$ by Map S. B-17 and $900-1,200 \mathrm{~m}$ by REMG.

The elevation of NPBR ranges from sea level in Mangroves of Tumbes National Sanctuary and from $200 \mathrm{~m}$ in northern Hills of Amotape National Park to $1,618 \mathrm{~m}$ at Carrizal Mountain (Figure 1) (Anon. 1988). Few mountains exceed $1,400 \mathrm{~m}$ in elevation. Avian survey sites and their elevations in Tumbes Department, Peru, were Santa Lucía (or Santa Luzia) and Puerto Pizarro: c.o m; Zorritos (or Sorritos): $6 \mathrm{~m}$, Tumbes (or Túmbez): $7 \mathrm{~m}$; Lechugal and Rica Playa: 
<150 m; El Caucho: c.400 m; La Laja: 610 m; Campo Verde: $750 \mathrm{~m}$; and Lajilla (or La Lajilla) (south of Figueroa): $700-900 \mathrm{~m}$. Collection sites in Piura Department, Peru, were Paita (or Payta): 3 m; Talara: 7 m; Piura: 29 m; Sullana: $60 \mathrm{~m}$; Somate (=Samate in Chapman 1926): <100 m; Romeros: c.100 m; Alamor (=Chapman's [1926] Lamor or La Lamor): $107 \mathrm{~m}$; Pilares: $230 \mathrm{~m}$; Chilaco: 100$400 \mathrm{~m}$; and El Angolo (or Angolo): 500-1,200 m. Collection sites from Loja Province, Ecuador, were Puyango (= Pullango or Rio Pullango): $275 \mathrm{~m}$ and/or $305 \mathrm{~m}$; Paletillas: $472 \mathrm{~m}$; Milagros: $670 \mathrm{~m}$; La Puente: $760 \mathrm{~m}$; Cebollal: $945 \mathrm{~m}$; Guainche: $975 \mathrm{~m}$; Las Piñas: 1,100 m; Vicentino: 900-1,450 m; and Alamor: $1,325 \mathrm{~m}$ and 1,200-1,450 $\mathrm{m}$. Collection sites in El Oro Province, Ecuador, were the "wetland": <50 m, Palmales (or Palmal): $93 \mathrm{~m}$, Santa Rosa and Arenillas: c. $100 \mathrm{~m}$, and Piedras: $<150 \mathrm{~m}$.

\section{Updating the ranges of the avifauna of NPBR's environs (area in Figure 1)}

The avifauna of the area depicted in Figure 1 is taxonomically arranged in the Appendix. However, the foremost reference books treating avian distributions there fail to place (or else misplace) many taxa appearing in the Appendix in the area of Figure 1. Exact observational or collection sites of these omitted or misplaced species and specific attributions for these avian records are provided below. It is hoped that this information will benefit many investigators as well as the authors of future publications addressing South American avian geography. Reference books treating multiple orders of birds that are particularly useful in examining ranges of South American taxa are Ridgely and Tudor's (1989, 1994) two volumes dealing with South American passerines, Blake's (1977) reference on Neotropical members of the parvclasses Ratitae and Galloanserae and the orders Gruiformes and Ciconiiformes (systematics and nomenclature accord with Sibley and Monroe 1990, 1993), as well as Sibley and Monroe's (1990, 1993) tomes on birds of the world, which can furnish ranges for remaining non-passerines. Use of "threatened" in the following account is based on global evaluations in Collar et al. (1992).

With respect to birds treated in Blake (1977), the following points apply. Taczanowski (1877a) specified that the Muscovy Duck Cairina moschata existed both at Palmal (=Palmales) in the Santa Rosa District of Guayaquil (now El Oro) Province, Ecuador, and at Tumbes, Peru (Figure 1). Also, Taczanowski (1886: 472-473) cited Johann Jacob von Tschudi's records of it on Peruvian ponds and coast, and reports of it in north-eastern Peru. J. Stolzmann (also spelled Sztolcman; see Vaurie 1972) collected three Cinnamon Teal Anas cyanoptera and three Black-necked Stilts Himantopus mexicanus at Santa Lucía (Figure 1) (Taczanowski 1877b, 1886: 383-384, 474-476). In Tumbes Department, A. Raimondi took a male Rufescent Tiger-heron Tigrisoma lineatum (Taczanowski 1886: 404-405) and Parker et al. (1989) observed the Rufous-necked Wood-rail Aramides axillaris. The Collared Plover Charadrius collaris was sighted west of Sullana and at Puerto Pizarro, Tumbes, and Piura (Figure 1) (Schulenberg and Parker 1981). Pierret and Hofmann (1967) observed the Black Skimmer Rynchops niger and South American Tern Sterna hirundinacea at or about Mangroves of Tumbes National Sanctuary (Figure 1). The Kelp Gull Larus dominicanus was noted at that sanctuary and at Paita (Figure 1) (Brooks 1917, O'Neill et al. 1988). 
Blake (1977: 87-88) indicated that the Great Grebe Podiceps major occurs in coastal Piura (Department) but because he gave no specific location this species does not appear in the Appendix. The Peruvian Booby Sula variegata has nested at Talara (Figure 1) (Chapman 1926: 214). At the "wetland" in the north-eastern corner of Figure 1, Bloch et al. (1991) observed the Least Bittern Ixobrychus exilis farther north along the Peruvian coast, and the Pinnated Bittern Botaurus pinnatus farther south (in Ecuador), than Blake (1977: 157-160) reported them.

Updating the ranges of members of the infraorder Falconides in Blake (1977), Wiedenfeld et al. (1985) sighted the Swallow-tailed Kite Elanoides forficatus, Grey-backed Hawk Leucopternis occidentalis (threatened), Short-tailed Hawk Buteo brachyurus, Zone-tailed Hawk Buteo albonotatus and Black Hawk-eagle Spizaetus tyrannus in the Reserved Zone of Tumbes (Figure1). Parker et al. (1989) heard the Barred Forest-falcon Micrastur ruficollis and saw the Bat Falcon Falco rufigularis there. Swainson's Hawk Buteo swainsoni has been seen about Tumbes and Piura (Figure 1) (Schulenberg and Parker 1981). In 1876 (Taczanowski 1877a,b, 1884a: 124-126, 138-140), J. Stolzmann collected an immature Plumbeous Kite Ictinia plumbea in Lechugal and an immature Black-chested Buzzard-eagle Geranoaetus melanoleucus in Tumbes. Taczanowski described examples of the Black-collared Hawk Busarellus nigricollis that had been collected in Santa Lucia (Figure 1) by A. Raimondi (Taczanowski 1884a: 111-113) and the Orange-breasted Falcon Falco deiroleucus that had been provided by Konstanty Jelski (Taczanowski 1884a: 149). Jelski reported that during his six-year stay in Peru he encountered the Orange-breasted Falcon only twice, once in Tumbes (Figure 1 ). Each collected falcon was eating a pigeon.

Concerning the avian distributions in Sibley and Monroe (1990, 1993), the following information applies. J. Stolzmann took a female Violaceous Trogon Trogon violaceus in Lechugal (Figure 1) but otherwise never encountered the species in Peru (Taczanowski 1877a, 1886: 173-175). The Olivaceous Piculet Picumnus olivaceus, Striped Cuckoo Tapera naevia, Lesser Swallow-tailed Swift Panyptila cayennensis and Green-crowned Woodnymph Thalurania fannyi (for nomenclature see Sibley and Monroe 1993: 28) have been recorded in Tumbes Department, Peru (Schulenberg and Parker 1981, Wiedenfeld et al. 1985, Parker et al. 1989). The Golden-headed Quetzal Pharomachrus auriceps and White-bellied Woodstar Acestrura mulsant were collected in Alamor, Ecuador (elevation: 1,325 m; Figure 1) (Chapman 1926: 329; Zimmer 1953). Occurring as far south as south-western Loja Province, Ecuador, are the Violet-tailed Sylph Aglaiocercus coelestis (Alamor) and Purple-crowned Fairy Heliothryx barroti (La Puente and Puyango) (Chapman 1925, 1926: 323). Zimmer's (1952) Aglaiocercus kingii aethereus equals $A$. coelestis aethereus (see Sibley and Monroe 1990: 162-163, Howard and Moore 1991: 159). The West Peruvian Screech-owl Otus roboratus has been recorded at elevations $\leqslant 400 \mathrm{~m}$ in Tumbes Department, Peru (Taczanowski 1884a: 185-187, Wiedenfeld et al. 1985). A. Raimondi collected a male Striped Owl Asio clamator in Tumbes (Taczanowski 1884a: 192-193).

With regard to the ranges of columbids provided by Sibley and Monroe (1990, 1993), it should be noted that in the Reserved Zone of Tumbes Wiedenfeld et al. (1985) reportedly observed the Plumbeous Pigeon Columba plumbea and Parker et al. (1989) sighted the Scaled Pigeon Columba speciosa, Ruddy Pigeon Columba subvinacea and Ochre-bellied Dove Leptotila ochraceiventris. There are Ecuadorian 
reports of the White-throated Quail-dove Geotrygon frenata in Alamor, Loja Province, and the Ruddy Quail-dove G. montana in Santa Rosa, El Oro Province (Figure 1) (Chapman 1922, 1926: 171-172). On 8 August 1899, Perry O. Simons collected a White-tipped Dove Leptotila verreauxi in Piura (Department) at an elevation of $30 \mathrm{~m}$ (Chubb 1919). This place may be in the vicinity of Catacaos, a short distance south-west of the city of Piura (Figure 1) (Vaurie 1972), where collections occurred on 4 August 1899.

To update Ridgely and Tudor's (1994) range data (text or maps), the following nine tyrannids have occurred in Tumbes Department, Peru (roughly north of Madre de Agua Creek, Figure 1): Ochre-bellied Flycatcher Mionectes oleagineus, Slaty-capped Flycatcher Leptopogon superciliaris, Golden-faced Tyrannulet Zimmerius chrysops, Rufous-winged Tyrannulet Mecocerculus calopterus, Tawny-crowned Pygmy-tyrant Euscarthmus meloryphus, Whitethroated Spadebill Platyrinchus mystaceus, Royal Flycatcher Onychorhynchus coronatus, Smoke-coloured Pewee Contopus fumigatus and Golden-winged Manakin Manacus manacus (Taczanowski 1877a, 1884b: 235, Bond 1947, Wiedenfeld et al. 1985, Parker et al. 1989). There are records of the Whitecrested Elaenia Elaenia albiceps in Alamor, Peru (Figure 1) (Zimmer 1941) and the Piratic Flycatcher Legatus leucophaius in Alamor, Ecuador (Best et al. 1992: 198). The Rusty-margined Flycatcher Myiozetetes cayanensis was taken in Cebollal (Figure 1) (Chapman 1926: 509-510). The specimen which Taczanowski labelled Myiozetetes similis (Social Flycatcher) in 1877 (1877a) was later renamed $M$. granadensis (Grey-capped Flycatcher) by him (1884b: 276277). Chapman (1926: 509-510), who never referred to Taczanowski's 1884 and 1886 works in cataloguing any species, assigned that specimen to $M$. cayanensis. That action has not been supported by other ornithologists (see Cory and Hellmayr 1927: 145-146, Zimmer 1937, Sibley and Monroe 1990: 366-367, Ridgely and Tudor 1994: 659).

The following thamnophilid and furnariid ranges provide corrections to Ridgely and Tudor (1994). Inhabiting the Reserved Zone of Tumbes (Figure 1) are Chapman's Antshrike Thamnophilus zarumae and the threatened Grey-headed Antbird Myrmeciza griseiceps (Wiedenfeld et al. 1985). The Russet Antshrike Thamnistes anabatinus has been recorded in Las Piñas, Ecuador (Figure 1) (Chapman 1926: 385). J. Stolzmann (Taczanowski 1877a) collected a male Cinereous Antshrike Thamnomanes caesius at Palmales (Figure 1). To my knowledge, there is no report of the Coastal Miner Geositta peruviana in Tumbes Department, Peru. Present there, however, are Azara's Spinetail Synallaxis azarae, the threatened Rufous-necked Foliage-gleaner Syndactyla ruficollis, Plain Xenops Xenops minutus, Plain-brown Woodcreeper Dendrocincla fuliginosa and Strong-billed Woodcreeper Xiphocolaptes promeropirhynchus (Zimmer 1934, Wiedenfeld et al. 1985, Parker et al. 1989).

In the superfamily Muscicapoidea, the following taxa have been noted in Tumbes Department (contra Ridgely and Tudor 1989): Spotted Nightingale-thrush Catharus dryas, Swainson's Thrush Catharus ustulatus, Grey-breasted Wood-wren Henicorhina leucophrys and Long-billed Gnatwren Ramphocaenus melanurus (Wiedenfeld et al. 1985, Parker et al. 1989). Within Ecuador, the Andean Solitaire Myadestes ralloides has been recorded in Alamor 
and the Whiskered Wren Thryothorus mystacalis has occurred in Alamor, Las Piñas and Vicentino (Chapman 1926: 565-566, 578; Best et al. 1992: 200).

Reports of these 18 fringillids in Tumbes Department, Peru, update Ridgely and Tudor's (1989) maps or textual descriptions of ranges: Black-striped Sparrow Arremonops conirostris, White-headed Brush-finch Atlapetes albiceps, Stripeheaded Brush-finch Atlapetes torquatus, Slate-throated Redstart Myioborus miniatus, Three-banded Warbler Basileuterus trifasciatus, Black-faced Tanager Schistochlamys melanopis, Black-and-white Tanager Conothraupis speculigera, Ashy-throated Bush-tanager Chlorospingus canigularis, Guira Tanager Hemithraupis guira, White-shouldered Tanager Tachyphonus luctuosus, Fawnbreasted Tanager Pipraeidea melanonota, Orange-bellied Euphonia Euphonia xanthogaster, Bay-headed Tanager Tangara gyrola, Collared Warbling-finch Poospiza hispaniolensis, Chestnut-throated Seedeater Sporophila telasco, Dullcoloured Grassquit Tiaris obscura, Blue-black Grosbeak Cyanocompsa cyanoides and Yellow-rumped Cacique Cacicus cela (Taczanowski 1877a,b; 1884b: 411-412, 547548, 554; 1886: 14-15, 30-31; Wiedenfeld et al. 1985; Parker et al. 1989). The Orange-billed Sparrow Arremon aurantiirostris, Buff-rumped Warbler Basileuterus fulvicauda and Green Honeycreeper Chlorophanes spiza were not reported by Taczanowski (1877a, 1884a: 435-436) to be in Tumbes, but in Palmales (Figure 1). The Chestnut-capped Brush-finch Atlapetes brunneinucha was taken in El Oro Province, Ecuador (Santa Rosa) (Chapman 1926: 635). Occurring as far south-west as southern Loja Province, Ecuador, are the Common Bush-tanager Chlorospingus ophthalmicus (Vicentino), Palm Tanager Thraupis palmarum (Las Piñas, Cebollal, Alamor and Vicentino), Blue-winged Mountain-tanager Anisognathus somptuosus (Alamor), Golden Tanager Tangara arthus (Puyango, Las Piñas, Alamor and Vicentino), Golden-naped Tanager Tangara ruficervix (Alamor), Swallow Tanager Tersina viridis (Cebollal and Alamor), Blackand-white Seedeater Sporophila luctuosa (Vicentino) and Russet-backed Oropendola Psarocolius angustifrons (Las Piñas) (Chapman 1926: 648, 657, 670, 673, 692; Zimmer 1943; Best et al. 1992: 205-206, 208).

Taczanowski (1886: 50-51) related that J. Stolzmann did not collect Chrysomitris siemiradzkii (Saffron Siskin) in the environs of Tumbes, where it was abundant, because he mistakenly thought that it was Chrysomitris capitalis. Chapman indicated that his Spinus peruanus paulus (1926: 621), represented by Ecuadorian specimens (including six from Milagros and Alamor), equals both von Berlepsch and Taczanowski's Chrysomitris capitalis (1883: 551) and Chrysomitris siemiradzkii (1884: 313). However, von Berlepsch and Taczanowski (1883: 551-52) did not make reference to $C$. capitalis but rather described $C$. siemiradzkii. Exacerbating the discrepancy, Chapman (1926: 622-623) indicated that his Spinus siemiradzkii equals von Berlepsch and Taczanowski's (1883: 536, 551) Chrysomitris siemiradskii (sp.). Chapman (1926: 621-622) did not synonymize either $C$. capitalis or $C$. siemiradzkii of von Berlepsch and Taczanowski with his Spinus (=Carduelis [see Sibley and Monroe 1990]) capitalis which had been recorded in Santa Rosa. Howard and Moore (1991: 502) regarded capitalis as a subspecies of the Hooded Siskin Carduelis magellanica, which ranges from southern Colombia to north-western Peru, paula as a subspecies that exists in southern Ecuador and western Peru, and peruana as a subspecies that inhabits 
central Peru. Wiedenfeld et al. (1985) collected one adult male and two immature siskins in the Reserved Zone of Tumbes, and tentatively identified them and sighted flocks of siskins as C. siemiradzkii.

\section{North American migrants}

Although Howard and Moore (1991) noted that one subspecies of Fulvous Whistling-duck Dendrocygna bicolor helva inhabits the southern U.S.A. and northern Mexico and another D. b. bicolor inhabits northern South America, Bellrose (1976) believed that the members of this species which invaded the U.S. Atlantic coast for more than a decade beginning in 1955 originated from northern South America. The migratory behaviour of this declining species (Scott 1987) needs to be understood. Parker et al. (1982) considered it to be rare in Peru but Marchant (1958) noted flocks of as many as 400 birds in the Santa Elena Peninsula of south-western Ecuador, an area located 122$157 \mathrm{~km}$ north-west of Mangroves of Tumbes National Sanctuary (Figure 1). At the latter site, O'Neill et al. (1988) recorded the migrant Blue-winged Teal Anas discors.

J. Stolzmann collected the Black-billed Cuckoo Coccyzus erythrophthalmus in Lechugal, and observed it along a road between Tumbes and Lechugal (Figure 1) during the rainy season (Taczanowski 1877a, 1886: 189-190). Stolzmann stated that K. Jelski collected two specimens that had eaten spiny caterpillars. Parker et al. (1982) indicated that this cuckoo is rare in Peru, where it occurs only in tropical habitats. Also, Stolzmann took the migrant Sora Porzana carolina at Santa Lucía (Taczanowski 1877b, 1886: 320-321).

Fourteen migrant scolopacids (Appendix) have occurred within the area delineated in Figure 1. J.Stolzmann collected eight of these species in Tumbes and two of the same species in Santa Lucia, and K. Jelski collected a ninth "somewhat rare" species (Marbled Godwit Limosa fedoa) in Tumbes River delta (Taczanowski 1877a,b; 1886: 354-356, 358-359, 364-365, 368-370, 373-375, 379383). Stolzmann stated that the Whimbrel Numenius phaeopus was fairly common. O'Neill et al. (1988) encountered three other tringines (Appendix) in what is now Mangroves of Tumbes National Sanctuary, and Bloch et al. (1991) recorded an additional pair of species (Appendix) in the wetland of Figure 1. Parker et al. (1982) indicated that in coastal Peru 11 of these 14 tringines were common or fairly common, the Red-necked Phalarope Phalaropus lobatus was uncommon, and the Marbled Godwit and Solitary Sandpiper Tringa solitaria were rare. At Santa Elena Peninsula, Ecuador, the Short-billed Dowitcher Limnodromus griseus and Least Sandpiper Calidris minutilla were abundant; the Lesser Yellowlegs Tringa flavipes, Spotted Sandpiper T. macularia and Willet Catoptrophorus semipalmatus were common; and the Whimbrel, Greater Yellowlegs Tringa melanoleuca, Solitary Sandpiper, Sanderling Calidris alba, Western Sandpiper C. mauri and Pectoral Sandpiper C. melanotos were uncommon (Marchant 1958). Hellmayr and Conover (1948b: 140-142) synonymized Taczanowski's (1877b, 1886: 373-375) Macrorhamphus griseus with the Long-billed Dowitcher Limnodromus scolopaceus. However, Blake (1977: 580582) and Sibley and Monroe (1990: 239) considered the dowitcher that migrates to Peru to be the Short-billed Dowitcher. 
J. Stolzmann collected a Grey Plover Pluvialis squatarola in Tumbes which Taczanowski (1877a, 1886: 338-340) described. O'Neill et al. (1988) recorded this species and the Semipalmated Plover Charadrius semipalmatus in Mangroves of Tumbes National Sanctuary (Figure 1). These migrant plovers are reportedly common in coastal Peru (Parker et al. 1982) and the Santa Elena Peninsula (Marchant 1958).

Eight migrant larids (Appendix) have been reported in the area of Figure 1. There have been collections of Franklin's Gull Larus pipixcan and the Royal Tern Sterna maxima in Paita by Captain Albert Hastings Markham, Sabine's Gull Xema sabini in Tumbes by J. B. Steere, and the Laughing Gull Larus atricilla, Royal Tern and Arctic Tern Sterna paradisaea in Santa Lucía by J. Stolzmann (Taczanowski 1877b, 1886: 439, 441-442, 450-452, 456-457; Saunders 1882). The Common Tern S. hirundo was noted in Talara (Hellmayr and Conover 1948b: 304-306) and the Black Tern Chlidonias niger was recorded about Mangroves of Tumbes National Sanctuary (Pierret and Hofmann 1967). The Gull-billed Tern Sterna nilotica and Sandwich Tern S. sandvicensis were reported in Piura Department by Plenge (1974) and Blake (1977: 636) respectively, but no specific localities were given. Later, O'Neill et al. (1988) recorded the Gull-billed Tern in Mangroves of Tumbes National Sanctuary. However, the Sandwich Tern is not included in the Appendix. Parker et al. (1982) indicated that in coastal Peru the Gull-billed Tern and Black Tern were rare, Sabine's Gull was uncommon, and the other five migrant larids (Appendix) were common or fairly common. At Santa Elena Peninsula, the Black Tern was rare, the Laughing Gull, Common Tern, and Arctic Tern were uncommon, the Gull-billed Tern and Royal Tern were common, and Franklin's Gull was abundant (Marchant 1958).

Although Parker et al. (1982) considered Swainson's Hawk to be rare in Peru, this migrant species and the migrant Osprey Pandion haliaetus have been recorded in the area shown in Figure 1 (Taczanowski 1877b, 1884a: 127-128, Schulenberg and Parker 1981, O'Neill et al. 1988). The Western Wood-pewee Contopus sordidulus (Myiochanes richardsoni of Chapman 1926: 525) was collected in Santa Rosa and Swainson's Thrush was observed in the Reserved Zone of Tumbes (Parker et al. 1989). Three swallow species (Appendix) migrate to the area delineated in Figure I (Schulenberg and Parker 1981). Parker et al. (1982) considered Swainson's Thrush and the three swallows to be rare in arid tropical habitats of Peru.

\section{Recommendations for the conservation of North-western Peru Biosphere Reserve}

The Reserved Zone of Tumbes comprises forests that are denser and more mesic than those in the other units of NPBR, and probably has the highest level of endemism and biological diversity. Moreover, this zone constitutes the terminus of the ranges of many avian species. Thus, it is the premier unit of NPBR and ought to be treated as such. Under the Sustained Use Plan for the Reserved Zone of Tumbes and its Buffer Zone (Fundación Peruana para la Conservación de la Naturaleza [FPCN] in litt.), most of the zone is designated as a strictly protected sector. Those parts of the zone where grazing or cultivation is allowed are its north-west wing, the upper part of its north-east wing, and a strip along 
its southern border (Figure 1). It is crucial that the strictly protected sector of the Reserved Zone of Tumbes, together with an abutting strip of land several kilometres wide, be ratified as a Category I (strict national reserve) or II (national park) sector by the Peruvian government's Institute Nacional de Recursos Naturales.

All livestock in the strictly protected sector should be removed with the possible exception of burros that are used to carry the equipment of special visitors to the Reserved Zone of Tumbes. Cowboys who have livestock in or about this sector should be notified that they have a certain period of time in which to remove their animals. Thereafter, the border police should have permission to hunt livestock for food. The pack animals that graze and defecate near El Caucho Biological Station should be kept $>2 \mathrm{~km}$ from the station.

Members of the Republican Guard should receive a governmental food stipend so that they do not feel a need to hunt birds such as Rufous-headed Chachalacas Ortalis erythroptera and Pale-browed Tinamous Crypturellus transfasciatus (see Best 1992: 228). Logging by the Republican Guard must be discontinued along the few roads that bisect the graded access road leading to the Reserved Zone of Tumbes. The police must help make regular and extensive patrols of the zone to protect its natural resources. One of the goals of FPCN, which manages NPBR, is to augment environmental awareness. Thus, it would be ideal for FPCN to instil in the Republican Guard a conservation ethic via seminars that would be attended by the commandant as well as rank-and-file police. To further reduce poaching and logging, other instructional sessions should be held for villagers and cowboys who live in the vicinity of the Reserved Zone of Tumbes.

In my view, at least six forest rangers (guardaparques) are needed in the Reserved Zone of Tumbes. In 1994, there was only one. The forest rangers should be conservationists who possess some college education, a basic understanding of ecology, and a conservation ethic. Their salary needs to be sufficient to attract applicants with these qualifications. Forest rangers need to follow a specific schedule each day and week, and keep a log of all their activities. They need to patrol remote areas as well as the vicinity of their lodging quarters. It is desirable that the rangers be transferred periodically so that they do not form close friendships with the neighbouring residents, cowboys or police.

\section{Acknowledgements}

I thank Brinley Best, Mercedes S. Foster, John P. O'Neill, and anonymous reviewers for their germane comments on earlier drafts of this paper. Also, I am grateful to the Fundación Peruana para la Conservación de la Naturaleza (FPCN) for providing me with publications and other useful information.

\section{References}

Anon. (1988) Plan operativo del Parque Nacional Cerros de Amotape. World Wildlife Fund and Fundación Peruana para la Conservación de la Naturaleza.

Balmaceda, C. E. (1986) Problemas y perspectivas de la veda del bosque seco tropical del noroeste. Pp.69-75 in Políticas y acciones 1986 a 1990 a cargo de la Dirección General 
de Forestal y Fauna y las direcciones forestales y de fauna de las regiones agrarias. Lima, Perú: Dirección General Forestal y de Fauna, Ministerio de Agricultura.

Bangs, O. and Noble, G. K. (1918) List of birds collected on the Harvard Peruvian expedition of 1916. Auk 35: 442-463.

Bellrose, F. C. (1976) Ducks, geese and swans of North America. Harrisburg, Pennsylvania: Stackpole Books.

von Berlepsch, H. and Taczanowski, L. (1883) Liste des oiseaux recueillis par MM. Stolzmann et Siemiradzki dans l'Ecuadeur occidental. Proc. Zool. Soc. London 1883: 536577 .

de Berlepsch, H. and Taczanowski, L. (1884) Deuxième liste des oiseaux recueillis dans l'Ecuadeur occidental par MM. Stolzmann et Siemiradski. Proc. Zool. Soc. London 1884: 281-313.

Best, B. (1992) The avian conservation importance of the forests of south-west Ecuador, with recommendations for further action. Pp.211-230 in B. J. Best, ed. The threatened forests of south-west Ecuador. Leeds, U.K.: Biosphere Publications.

Best, B., Broom, A., Checker, M. and Thewlis, R. (1992) An ornithological survey of El Oro and western Loja Provinces, south-west Ecuador, January-March 1991. Pp.137210 in B. J. Best, ed. The threatened forests of south-west Ecuador. Leeds, U.K.: Biosphere Publications.

Blake, E. R. (1977) Manual of neotropical birds, 1. Chicago: University of Chicago Press.

Bloch, H., Poulsen, M. K., Rahbek, C. and Rasmussen, J. F. (1991) A survey of the montane forest avifauna of the Loja Province, southern Ecuador. Cambridge, U.K.: International Council for Bird Preservation (Study Report 49).

Bond, J. (1945) Notes on Peruvian Furnariidae. Proc. Acad. Nat. Sci. Philadelphia 97: 17-39.

Bond, J. (1947) Notes on Peruvian Tyrannidae. Proc. Acad. Nat. Sci. Philadelphia 99: 127154 .

Bond, J. (1950) Notes on Peruvian Formicariidae. Proc. Acad. Nat. Sci. Philadelphia 102: $1-26$.

Bond, J. (1951) Notes on Peruvian Fringillidae. Proc. Acad. Nat. Sci. Philadelphia 103: 65-84.

Bond, J. (1953) Notes on Peruvian Icteridae, Vireonidae and Parulidae. Notulae Naturae 255.

Bond, J. (1955) Additional notes on Peruvian birds I. Proc. Acad. Nat. Sci. Philadelphia 107: 207-244.

Bond, J. (1956) Additional notes on Peruvian birds II. Proc. Acad. Nat. Sci. Philadelphia 108: 227-247.

Brooks, W. S. (1917) Notes on some Falkland Island birds. Bull. Mus. Comp. Zool. 61: $135^{-160 .}$

Carriker, M. A., Ir (1935) Descriptions of new birds from Peru and Ecuador, with critical notes on other little-known species. Proc. Acad. Nat. Sci. Philadelphia 87: 343-359.

Chapman, F. M. (1917) The distribution of bird-life in Colombia: a contribution to a biological survey of South America. Bull. Amer. Mus. Nat. Hist. 36: 1-729.

Chapman, F. M. (1919) Descriptions of proposed new birds from Peru, Bolivia, Brazil, and Colombia. Proc. Biol. Soc. Washington 32: 253-268.

Chapman, F. M. (1921) Descriptions of proposed new birds from Colombia, Ecuador, Peru and Brazil. Amer. Mus. Novit. 18.

Chapman, F. M. (1922) Descriptions of apparently new birds from Colombia, Ecuador, and Argentina. Amer. Mus. Novit. 31.

Chapman, F. M. (1923) Descriptions of new Formicariidae and Dendrocolaptidae. Amer. Mus. Novit. 86.

Chapman, F. M. (1924) Descriptions of new birds from Ecuador, Colombia, Peru, and Bolivia. Amer. Mus. Novit. 138.

Chapman, F. M. (1925) Descriptions of new birds from Ecuador and Peru. Amer. Mus. Novit. 187. 
Chapman, F. M. (1926) The distribution of bird-life in Ecuador: a contribution to a study of the origin of Andean bird-life. Bull. Amer. Mus. Nat. Hist. 55: 1-784.

Chubb, C. (1919) Notes on collections of birds in the British Museum, from Ecuador, Peru, Bolivia, and Argentina. Ibis 11(1): 1-55.

Collar, N. J., Gonzaga, L. P., Krabbe, N., Madroño Nieto, A., Naranjo, L. G., Parker III, T. A. and Wege, D. C. (1992) Threatened birds of the Americas: the ICBP/IUCN Red Data Book. Cambridge, U.K.: International Council for Bird Preservation.

Cory, C. B. (1918) Catalogue of birds of the Americas and the adjacent islands. Field Mus. Nat. Hist., Zool. Series, Publ. 197, 13 (Part 2, No. 1).

Cory, C. B. (1919) Catalogue of birds of the Americas and the adjacent islands. Field Mus. Nat. Hist., Zool. Series, Publ. 203, 13 (Part 2, No. 2).

Cory, C. B. and Hellmayr, C. E. (1924) Catalogue of birds of the Americas and the adjacent islands. Field Mus. Nat. Hist., Zool. Series, Publ. 223, 13 (Part 3).

Cory, C. E. and Hellmayr, C. E. (1925) Catalogue of birds of the Americas and the adjacent islands. Field Mus. Nat. Hist., Zool. Series, Publ. 234, 13 (Part 4).

Cory, C. E. and Hellmayr, C. E. (1927) Catalogue of birds of the Americas and the adjacent islands. Field Mus. Nat. Hist., Zool. Series, Publ. 242, 13 (Part 5).

Hellmayr, C. E. (1929) Catalogue of birds of the Americas and the adjacent islands. Field Mus. Nat. Hist., Zool. Series, Publ. 266, 13 (Part 6).

Hellmayr, C. E. (1934) Catalogue of birds of the Americas and the adjacent islands. Field Mus. Nat. Hist., Zool. Series, Publ. 330, 13 (Part 7).

Hellmayr, C. E. (1935) Catalogue of birds of the Americas and the adjacent islands. Field Mus. Nat. Hist., Zool. Series, Publ. 347, 13 (Part 8).

Hellmayr, C. E. (1936) Catalogue of birds of the Americas and the adjacent islands. Field Mus. Nat. Hist., Zool. Series, Publ. 365, 13 (Part 9).

Hellmayr, C. E. (1937) Catalogue of birds of the Americas and the adjacent islands. Field Mus. Nat. Hist., Zool. Series, Publ. 381,13 (Part 10).

Hellmayr, C. E. (1938) Catalogue of birds of the Americas and the adjacent islands. Field Mus. Nat. Hist., Zool. Series, Publ. 430, 13 (Part 11).

Hellmayr, C. E. and Conover, B. (1942) Catalogue of birds of the Americas and the adjacent islands. Field Mus. Nat. Hist., Zool. Series, Publ. 514, 13 (Part 1, No. 1).

Hellmayr, C. E. and Conover, B. (1948a) Catalogue of birds of the Americas and the adjacent islands. Field Mus. Nat. Hist., Zool. Series, Publ. 615, 13 (Part 1, No. 2).

Hellmayr, C. E. and Conover, B. (1948b) Catalogue of birds of the Americas and the adjacent islands. Field Mus. Nat. Hist., Zool. Series, Publ. 616, 13 (Part 1, No. 3).

Hellmayr, C. E. and Conover, B. (1949) Catalogue of birds of the Americas and the adjacent islands. Field Mus. Nat. Hist., Zool. Series, Publ. 634, 13 (Part 1, No. 4).

Howard, R. and Moore, A. (1991) A complete checklist of the birds of the world. Second edition. London: Academic Press.

Lawrence, G. N. (1871) Descriptions of new species of birds of the families Troglodytidae and Tyrannidae. Proc. Acad. Nat. Sci. Philadelphia 23: 233-236.

Lawrence, G. N. (1874) Descriptions of new species of birds of the genera Icterus and Synallaxis. Ann. Lyceum Nat. Hist. 10: 184-186.

de Macedo-Ruiz, H. (1979) "Extinct" bird found in Peru. Oryx 15: 33-37.

Marchant, S. (1958) The birds of the Santa Elena Peninsula, S.W. Ecuador. Ibis 100: 349387 .

O'Neill, J. P. and a planning team (1988) Especies de fauna del manglar. Pp.124-125 in Plan operativo del Parque Nacional Cerros de Amotape. World Wildlife Fund and Fundación Peruana para la Conservación de la Naturaleza.

Parker, T. A., III, Parker, S. A. and Plenge, M. A. (1982) An annotated checklist of Peruvian birds. Vermillion, South Dakota: Buteo Books. 
Parker, T. A., III, Schulenberg, T. S., Kessler, M. and Wüst, W. (1989) Species limits, natural history, and conservation of some endemic birds in north-west Peru. Unpublished manuscript (but see Bird Conservation International 5: 201-231).

Paynter, R. A., Jr and Traylor, M. A., Jr (1977) Ornithological gazetteer of Ecuador. Cambridge, Massachusetts: Museum of Comparative Zoology.

Peñaherrera del Aguila, C., ed. (1989) Atlas del Perú. Lima: República del Perú, Ministerio de Defensa, Instituto Geográfico Nacional.

Pierret, P. V. and Hofmann, A. (1967) Viaje de información sobre la situación actual de la fauna de los departamentos de Tumbes, Piura y Cajamarca (Perí). Sugerencias para una politica de conservación. La Molina, Perú: Instituto de Investigaciones Forestales (Informe No. 9., Universidad Nacional Agraria, La Molina, and Servicio Forestal y de Caza).

Plenge, M. A. (1974) Notes on some birds in west-central Perú. Condor 76: 326-330.

Ridgely, R. S. and Tudor, G. (1989) The birds of South America, 1: the oscine passerines. Austin: University of Texas Press.

Ridgely, R. S. and Tudor, G. (1994) The birds of South America, 2: the suboscine passerines. Austin: University of Texas Press.

Salvin, O. (1883) A list of birds collected by Captain A. H. Markham on the west coast of America. Proc. Zool. Soc. London 1883: 419-432.

Salvin, O. (1896) Order XIV. Tubinares. Cat. Birds Brit. Mus. 25: 340-455 + plates 2-8.

Saunders, H. (1882) On some Laridae from the coasts of Peru and Chili, collected by Capt. Albert H. Markham, R.N., with some remarks on the geographical distribution of the group in the Pacific. Proc. Zool. Soc. London 1882: 520-530 + plate 34 .

Schulenberg, T. S. and Parker, T. A., III (1981) Status and distribution of some northwest Peruvian birds. Condor 83: 209-216.

Scott, S. L., ed. (1987) Field guide to birds of North America. Second edition. Washington, D.C.: National Geographic Society.

Sibley, C. G. and Monroe, B. L. (1990) Distribution and taxonomy of birds of the world. New Haven, Connecticut: Yale University Press.

Sibley, C. G. and Monroe, B. L. (1993) A supplement to: Distribution and taxonomy of birds of the world. New Haven, Connecticut: Yale University Press.

Simon, E. (1901) Descriptions de trois espèces nouvelles de la famille des Trochilidae. Ornis, Bulletin du Comité Ornithologique International 11: 201-203.

Taczanowski, L. (1877a) Liste des oiseaux recueillis en 1876 au nord du Pérou occidental par MM. Jelski et Stolzmann. Proc. Zool. Soc. London 1877: 319-333 + plate 36.

Taczanowski, L. ( 1877 b) Supplément à la liste des oiseaux recueillis au nord du Pérou occidental par MM. Jelski et Stolzmann. Proc. Zool. Soc. London 1877: 744-754.

Taczanowski, L. (1884a) Ornithologie du Pérou, 1. Paris: Typographie Oberthur, A. Rennes.

Taczanowski, L. (1884b) Ornithologie du Pérou, 2. Paris: Typographie Oberthur, A. Rennes.

Taczanowski, L. (1886) Ornithologie du Pérou, 3. Paris: Typographie Oberthur, A. Rennes.

Taczanowski, L. and von Berlepsch, H. (1885) Troisième liste des oiseaux recueillis par M. Stolzmann dans l'Ecuadeur. Proc. Zool. Soc. London 1885: 67-124.

Vaurie, C. (1972) An ornithological gazetteer of Peru (based on information compiled by J. T. Zimmer). Amer. Mus. Novit. 2491.

Wiedenfeld, D. A., Schulenberg, T. S. and Robbins, M. B. (1985) Birds of a tropical deciduous forest in extreme northwestern Peru. Pp.305-315 in P.A. Buckley, M. S. Foster, E. S. Morton, R. S. Ridgely and F. G. Buckley, eds. Neotropical ornithology. Washington, D.C.: American Ornithologists' Union (Orn. Monogr. 36).

Winkler, H., Christie, D. A. and Nurney, D. (1995) Woodpeckers: a guide to the woodpeckers of the world. Boston: Houghton Mifflin Co. 
Zimmer, J. T. (1934) Studies of Peruvian birds. No. 14. Notes on the genera Dendrocolaptes, Hylexetastes, Xiphocolaptes, Dendroplex, and Lepidocolaptes. Amer. Mus. Novit. 753 .

Zimmer, J. T. (1937) Studies of Peruvian birds. No. 28. Notes on the genera Myiodynastes, Conopias, Myiozetetes, and Pitangus. Amer. Mus. Novit. 963.

Zimmer, J. T. (1941) Studies of Peruvian birds. No. 36. The genera Elaenia and Myiopagis. Amer. Mus. Novit. 1108.

Zimmer, J. T. (1943) Studies of Peruvian birds. No. 46. The genus Tangara (Part 1). Amer. Mus. Novit. 1245.

Zimmer, J. T. (1950) Studies of Peruvian birds. No. 59. The genera Polytmus, Leucippus, and Amazilia. Amer. Mus. Novit. 1475.

Zimmer, J. T. (1951) Studies of Peruvian birds. No. 60. The genera Heliodoxa, Phlogophilus, Urosticte, Polyplancta, Adelomyia, Coeligena, Ensifera, Oreotrochilus, and Topaza. Amer. Mus. Novit. 1513.

Zimmer, J. T. (1952) Studies of Peruvian birds. No. 62. The hummingbird genera Patagona, Sappho, Polyonymus, Ramphomicron, Metallura, Chalcostigma, Taphrolesbia, and Aglaiocercus. Amer. Mus. Novit. 1595.

Zimmer, J. T. (1953) Studies of Peruvian birds. No. 63. The hummingbird genera Oreonympha, Schistes, Heliothryx, Loddigesia, Heliomaster, Rhodopis, Thaumastura, Calliphlox, Myrtis, Myrmia, and Acestrura. Amer. Mus. Novit. 1604.

\section{A. GAYLON COOK}

Bioconservation International, 3306 N Canyon Rd, Provo, Utah, 84604-4548, U.S.A.

\section{Appendix. Taxonomically ordered list of birds inhabiting elevations $\leqslant 1,450 \mathrm{~m}$ in the environs of North-western Peru Biosphere Reserve.}

Nomenclature and taxonomic arrangement accord with Sibley and Monroe (1990, 1993). Chapman's Antshrike Thamnophilus zarumae and the Western Slatyantshrike Thamnophilus atrinucha are considered to be full species (Ridgely and Tudor 1994: 229, 240-241; see Sibley and Monroe 1990: 381; 1993: 49).

Key:

* Within the region shown in Figure 1, these species have been recorded only in Ecuador.

$\$$ North American migrant.

+ Endemic to the provinces of El Oro and Loja in extreme south-western Ecuador, and the departments of Tumbes, Piura and Lambayeque in extreme north-western Peru (see Blake 1977, Ridgely and Tudor 1989, 1994, Sibley and Monroe 1990, Collar et al. 1992, Winkler et al. 1995).

‡ Threatened (Collar et al. 1992), but not endemic to the strip of western political units in Ecuador and Peru which is defined above.

A superscripted letter is used to signify, for each species, the earliest source or one of the earliest sources of a specific locality report within the area depicted in Figure 1 . These attributions are listed in roughly chronological order below. If a taxon was first recorded at an Ecuadorian site within Figure 1 and subsequently reported at a Peruvian location in Figure 1 , the earliest source of a Peruvian record is indicated. In referring to several of the references below, note that Milagros and Paletillas are in Ecuador, not Peru (see 
text), and that the Ecuadorian sites of Las Piñas, Lojas Province (Figure 1) and Piñas, El Oro Province, are distinct. Sabanilla, Ecuador, to which several authors below refer ( $4^{\circ} \mathrm{O}^{\prime} \mathrm{S} 79^{\circ} \mathrm{O}^{\prime} \mathrm{W}$ : Paynter and Traylor 1977), is not the same place as the Sabanilla shown in Figure 1. Only Best et al. (1992) and Collar et al. (1992) allude to the Sabanilla of Figure 1.

Lawrence (1871, 1874).

Taczanowski (1877a,b, 1884a,b, 1886) and Taczanowski and von Berlepsch (1885: 122) provided early avian records (mostly based on specimens) from Tumbes, Santa Lucía, Lechugal and Palmales (Figure 1). Notes in Taczanowski (1884a: 89-91; 1886: 391-392, 424-425) signify that three widespread members of the parvorder Ciconiida existed in the area of Figure 1 even though a specific site record was not provided for any of them. J. Stolzmann reported that the Great Egret Casmerodius albus was "distributed in all of northern Peru, especially on the coast", J. J. Tschudi noted that the Peruvian Pelican Pelecanus thagus occurred "along all the Peruvian coast", and Alcide Dessalines d'Orbigny related that the Turkey Vulture Cathartes aura inhabited the entire Peruvian coast from Chile to Ecuador (my italics). For synonymies of Taczanowski's binomials, see Cory (1918, 1919), Cory and Hellmayr (1924, 1925, 1927), Hellmayr (1929, 1934, 1935, 1936, 1937, 1938), and Hellmayr and Conover (1942, 1948a,b, 1949); see also Sibley and Monroe (1990, 1993) and Howard and Moore (1991). Taczanowski (1884a: 104-106) indicated that the specimen which he had previously $(1877 \mathrm{~b})$ classified as Urubitinga anthracina should have been named $U$. zonura (= Great Black-hawk Buteogallus urubitinga). Taczanowski (1884a: 109-110) described the Mangrove Blackhawk Buteogallus subtilis using the binomial Urubitinga schistacea. L. Stolzmann declared that this species was the most common raptor at the mouth of Tumbes River, where it occurred in flocks and fed on crabs (Taczanowski 1884a: 109-110). Hellmayr and Conover (1949: 188-192) examined one or both of the specimens of this species that had been collected by Stolzmann at Santa Lucía and labelled by Taczanowski (1877b, 1884a: 109-110) as U.schistacea, and found it or them to be the Mangrove Black-hawk. In addition, these authors (pp.179-180) considered both specimens (or the second specimen) so labelled to be Plumbeous Hawks Leucopternis plumbea.

sr Saunders (1882).

sn Salvin (1883, 1896).

sm Simon (1901).

c Chapman (1917: 384; 1919; 1921; 1922; 1923; 1924; 1925; 1926). In 1919, Chapman mistakenly referred to Alamor, Ecuador (elevation c.1.310 m), as Alamor, Peru. For synonymies of Chapman's binomials, see the sources given above for finding synonymies of Taczanowski's scientific names.

bk Brooks (1917).

bg Bangs and Noble (1918).

cb Chubb (1919).

cy Cory and Hellmayr (1924: 144).

h Hellmayr (1934: 177), Hellmayr and Conover (1948a: 50-51, 67-69, 102-103, 398-399; 1948b: 304-306, 319-320).

z Zimmer (1934, 1941, 1951, 1953).

bd Bond (1945, 1947, 1950, 1951, 1953, 1955, 1956). 
pt Pierret and Hofmann (1967). In Tumbes Department, these authors identified 19 avian species in mangroves.

s Schulenberg and Parker (1981). These authors' Petrochelidon fulva equals Hirundo rufocollaris (Chestnut-sided Swallow) of this table.

wiedenfeld et al. (1985).

P Parker et al. (1989).

b Bloch et al. (1991).

cr Collar et al. (1992: 784-786). Specimens of the Grey-breasted Flycatcher Lathrotriccus griseipectus were collected at El Angolo in November 1972.

bt Best et al. (1992: 195, 198, 205-206, 208).

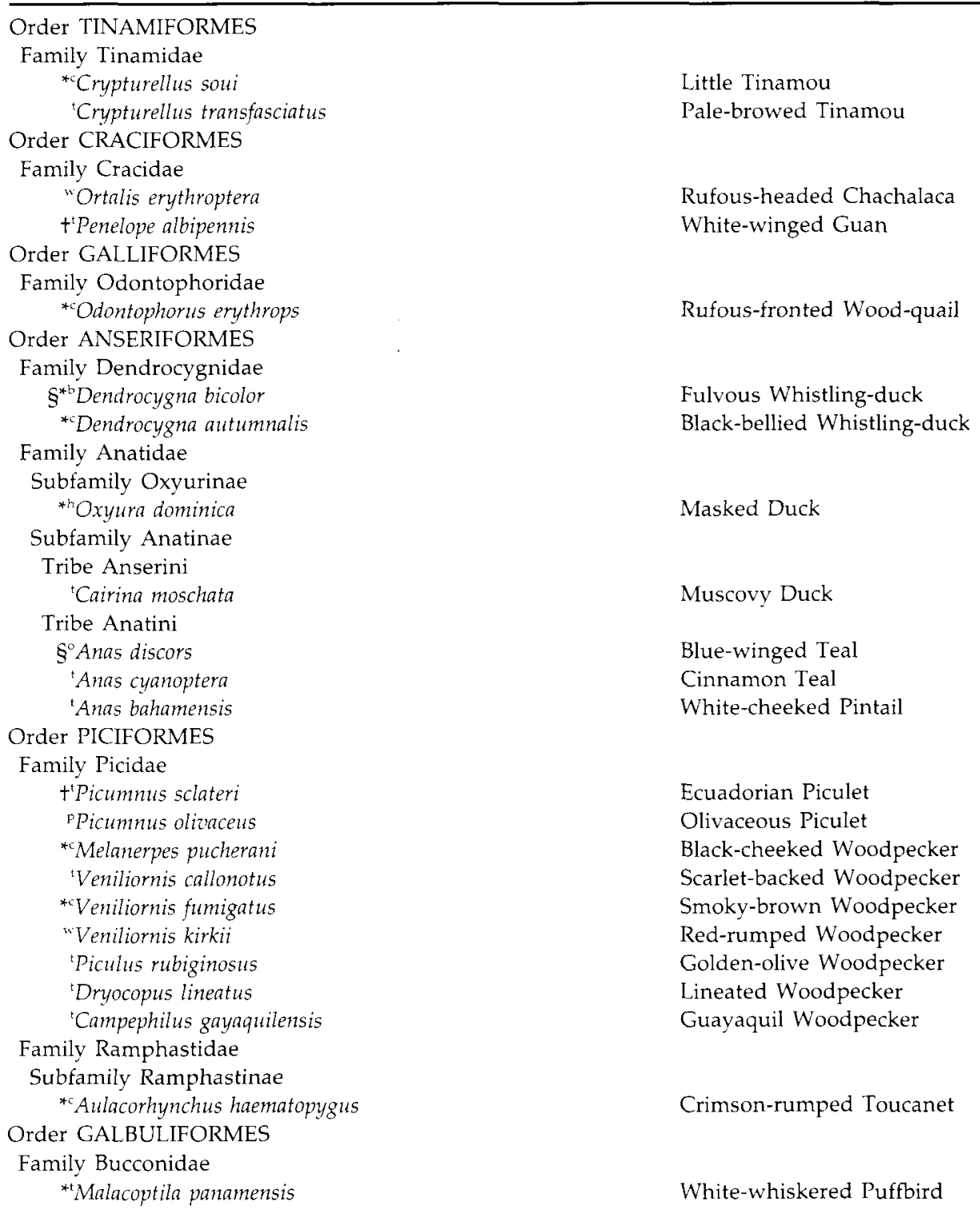




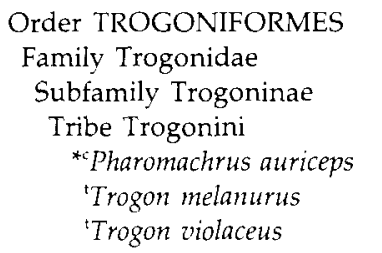

Order CORACIIFORMES

Family Momotidae 'Momotus momota

Family Cerylidae

'Megaceryle torquata

'Chloroceryle americana

* Chloroceryle inda

Order CUCULIFORMES

Family Coccyzidae $\S^{\dagger}$ Coccyzus erythrophthalmus

'Piaya cayana

* Piaya minuta

Family Crotophagidae

Tribe Crotophagini

*Crotophaga ani

${ }^{t}$ Crotophaga sulcirostris

Family Neomorphidae

${ }^{\text {sTapera naevia }}$

Order PSITTACIFORMES

Family Psittacidae

${ }^{t}$ Aratinga erythrogenys

${ }^{t}$ Forpus coelestis

${ }^{\mathrm{t}}$ Brotogeris pyrrhopterus

* Pionus menstruus

bd Pionus chalcopterus

Order APODIFORMES

Family Apodidae

"Streptoprocne zonaris

${ }^{\text {w }}$ Chaetura cinereiventris

"Chaetura brachyura

sanyptila cayennensis

Order TROCHILIFORMES

Family Trochilidae

Subfamily Phaethornithinae

"Phaethornis superciliosus

'Phaethornis griseogularis

Subfamily Trochilinae

'Anthracothorax prevostii

PThalurania fannyi

"Damophila julie

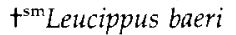

* Amazilia franciae

*Amazilia tzacatl

'Amazilia amazilia

"Chalybura buffonit

*zAdelomyia melanogenys

* Heliodoxa jacula

*cocreatus underwoodi

* Aglaiocercus coelestis

*cHeliothryx barroti
Golden-headed Quetzal

Black-tailed Trogon

Violaceous Trogon

Blue-crowned Motmot

Ringed Kingfisher

Green Kingfisher

Green-and-rufous Kingfisher

Black-billed Cuckoo

Squirrel Cuckoo

Little Cuckoo

Smooth-billed Ani

Groove-billed Ani

Striped Cuckoo

Red-masked Parakeet

Pacific Parrotlet

Grey-cheeked Parakeet

Blue-headed Parrot

Bronze-winged Parrot

White-collared Swift

Grey-rumped Swift

Short-tailed Swift

Lesser Swallow-tailed Swift

Long-tailed Hermit

Grey-chinned Hermit

Green-breasted Mango

Green-crowned Woodnymph

Violet-bellied Hummingbird

Tumbes Hummingbird

Andean Emerald

Rufous-tailed Hummingbird

Amazilia Hummingbird

White-vented Plumeleteer

Speckled Hummingbird

Green-crowned Brilliant

Booted Racket-tail

Violet-tailed Sylph

Purple-crowned Fairy 
${ }^{\mathrm{t}}$ Heliomaster longirostris

${ }^{2}$ Rhodopis vesper

'Myrmia micrura

* Acestrura mulsant

$\ddagger^{* c}$ Acestrura bombus

Order STRIGIFORMES

Family Strigidae

Otus roboratus

PStrix nigrolineata

${ }^{\text {t} P u l s a t r i x}$ perspicillata

${ }^{\dagger}$ Glaucidium brasilianum

'Speotyto cunicularia

${ }^{\dagger}$ Asio clamator

Family Caprimulgidae

Subfamily Chordeilinae

${ }^{t} \mathrm{Chordeiles}$ acutipennis

Subfamily Caprimulginae

'Nyctidromus albicollis

Order COLUMBIFORMES

Family Columbidae

PColumba speciosa

"Columba plumbea

PColumba subvinacea

'Zenaida auriculata

'Zenaida asiatica

'Columbina bucklevi

'Columbina cruziana

'Claravis pretiosa

ch Leptotila verreauxi

$\ddagger^{\mathrm{P} L e p t o t i l a}$ ochraceiventris

*Geotrygon frenata

* Geotrygon montana

Order GRUIFORMES

Family Rallidae

${ }^{t}$ Rallus longirostris

PAramides axillaris

§'Porzana carolina

* Porphyrio martinicus

Order CICONIIFORMES

Family Scolopacidae

Subfamily Tringinae

§Limosa fedoa

$\S^{\mathrm{t} N u m e n i u s ~ p h a e o p u s}$

$\S^{* b}$ Tringa melanoleuca

§oTringa flavipes

$\S$ Tringa solitaria

$\S^{\mathrm{t}}$ Tringa macularia

$\$$ Catoptrophorus semipalmatus

\$Limnodromus griseus

$\S^{\mathrm{t} C a l i d r i s}$ canutus

$\S^{\circ}$ Calidris alba

$\S^{\circ}$ Calidris mauri

$\S^{\dagger}$ Calidris minutilla

$\S^{* \mathrm{~b}}$ Calidris melanotos

\$ Phalaropus lobatus

Family Jacanidae

Jacana jacana
Long-billed Starthroat

Oasis Hummingbird

Short-tailed Woodstar

White-bellied Woodstar

Little Woodstar

West Peruvian Screech-owl

Black-and-white Owl

Spectacled Owl

Ferruginous Pygmy-owl

Burrowing Owl

Striped Owl

Lesser Nighthawk

Pauraque

Scaled Pigeon

Plumbeous Pigeon

Ruddy Pigeon

Eared Dove

White-winged Dove

Ecuadorian Ground-dove

Croaking Ground-dove

Blue Ground-dove

White-tipped Dove

Ochre-bellied Dove

White-throated Quail-dove

Ruddy Quail-dove

Clapper Rail

Rufous-necked Wood-rail

Sora

Purple Gallinule

Marbled Godwit

Whimbrel

Greater Yellowlegs

Lesser Yellowlegs

Solitary Sandpiper

Spotted Sandpiper

Willet

Short-billed Dowitcher

Red Knot

Sanderling

Western Sandpiper

Least Sandpiper

Pectoral Sandpiper

Red-necked Phalarope

Wattled Jacana 
Family Burhinidae

'Burhinus stuperciliaris

Peruvian Thick-knee

Family Charadriidae

Subfamily Recurvirostrinae

Tribe Haematopodini

${ }^{'}$ Haematopus palliatus

Tribe Recurvirostrini

'Himantopus mexicanus

Subfamily Charadriinae

$\S$ Pluvialis squatarola

$\varsigma^{\circ}$ Charadrius semipalmatus

'Charadrius wilsonia

"Charadrius vociferus

${ }^{5}$ Charadrius collaris

Family Laridae

Subfamily Larinae

Tribe Rynchopini

${ }^{\mathrm{Pt}}$ Rynchops niger

Tribe Larini

${ }^{b k}$ Larus dominicanus

${ }^{5}$ Larus cirrocephalus

G'Larus atricilla

$\S^{5 r}$ Larus pipixcan

$\S^{t}$ Xema sabini

${ }^{c}$ Creagrus furcatus

Tribe Sternini

SoSterna nilotica

S'Sterna maxima

ptSterna hirundinacea

$\S^{h}$ Sterna hirundo

\$'Sterna paradisaea

${ }^{\mathrm{h}}$ Sterna lorata

$\S^{\text {rt } C h l i d o n i a s ~ n i g e r ~}$

Family Accipitridae

Subfamily Pandioninae

\$Pandion haliaetus

Subfamily Accipitrinae

"Elanoides forficatus

'Gampsonyx swainsonii

'Ictinia plumbea

"Accipiter ventralis

'Accipiter bicolor

'Geranospiza caerulescens

'Leucopternis plumbea

$\ddagger^{w}$ Leucopternis occidentalis

${ }^{'}$ Buteogallus subtilis

${ }^{t}$ Buteogallus urubitinga

* Buteogallus meridionalis

'Parabuteo unicinctus

'Busarellus nigricollis

'Geranoaetus melanoleucus

PButeo magnirostris

"Buteo brachyurus

$\S^{s}$ Buteo swainsoni

${ }^{\text {t} B u t e o ~ p o l y o s o m a ~}$

"Buteo albonotatus

"Spizaetus tyrannus

American Oystercatcher

Black-necked Stilt

Grey Plover

Semipalmated Plover

Wilson's Plover

Killdeer

Collared Plover

Black Skimmer

Kelp Gull

Grey-headed Gull

Laughing Gull

Franklin's Gull

Sabine's Gull

Swallow-tailed Gull

Gull-billed Tern

Royal Tern

South American Tern

Common Tern

Arctic Tern

Peruvian Tern

Black Tern

Osprey

Swallow-tailed Kite

Pearl Kite

Plumbeous Kite

Plain-breasted Hawk

Bicoloured Hawk

Crane Hawk

Plumbeous Hawk

Grey-backed Hawk

Mangrove Black-hawk

Great Black-hawk

Savanna Hawk

Harris's Hawk

Black-collared Hawk

Black-chested Buzzard-eagle

Roadside Hawk

Short-tailed Hawk

Swainson's Hawk

Red-backed Hawk

Zone-tailed Hawk

Black Hawk-eagle 
${ }^{t}$ Spizaetus ornatus

Family Falconidae

${ }^{t}$ Polyborus plancus

${ }^{t}$ Herpetotheres cachinnans

${ }^{\mathrm{P}}$ Micrastur ruficollis

${ }^{\dagger} M i c r a s t u r$ semitorquatus

${ }^{\text {snFalco sparverius }}$

'Falco femoralis

${ }^{\mathrm{P}}$ Falco rufigularis

'Falco deiroleucus

Family Podicipedidae

'Tachybaptus dominicus

* Podilymbus podiceps

Family Sulidae

-Sula nebouxii

'Sula variegata

'Sula dactylatra

Family Anhingidae

*b Anhinga anhinga

Family Phalacrocoracidae

'Phalacrocorax brasilianus

PtPalacrocorax bougainvillii

Family Ardeidae

${ }^{t}$ Egretta tricolor

${ }^{t}$ Egretta caerulea

${ }^{t}$ Egretta thula

'Ardea cocoi

${ }^{t}$ Casmerodius albus

*bubulcus ibis

${ }^{t} B$ utorides striatus

'Nyctanassa violacea

${ }^{t}$ Nycticorax nycticorax

${ }^{t}$ Tigrisoma lineatum

*b Ixobrychus exilis

*botaurus pinnatus

Family Phoenicopteridae

'Phoenicopterus chilensis

Family Threskiornithidae

${ }^{t}$ Eudocimus albus

'Ajaia ajaja

Family Pelecanidae

Subfamily Pelecaninae

'Pelecanus occidentalis

'Pelecanus thagus

Family Ciconiidae

Subfamily Cathartinae

'Coragyps atratus

'Cathartes aura

'Sarcoramphus papa

Subfamily Ciconiinae

'Mycteria americana

Family Fregatidae

tFregata magnificens

Family Procellariidae

Subfamily Procellariinae

${ }^{\mathrm{h}}$ Macronectes giganteus

"Daption capense
Ornate Hawk-eagle

Crested Caracara

Laughing Falcon

Barred Forest-falcon

Collared Forest-falcon

American Kestrel

Aplomado Falcon

Bat Falcon

Orange-breasted Falcon

Least Grebe

Pied-billed Grebe

Blue-footed Booby

Peruvian Booby

Masked Booby

Anhinga

Neotropic Cormorant

Guanay Cormorant

Tricoloured Heron

Little Blue Heron

Snowy Egret

Cocoi Heron

Great Egret

Cattle Egret

Striated Heron

Yellow-crowned Night-heron

Black-crowned Night-heron

Rufescent Tiger-heron

Least Bittern

Pinnated Bittern

Chilean Flamingo

White Ibis

Roseate Spoonbill

Brown Pelican

Peruvian Pelican

Black Vulture

Turkey Vulture

King Vulture

Wood Stork

Magnificent Frigatebird

Antarctic Giant-petrel

Cape Petrel 
${ }^{\mathrm{h}}$ Puffinus bulleri

"Puffinus griseus

Subfamily Diomedeinae

'Diomedea irrorata

Subfamily Hydrobatinae

'Oceanites gracilis

${ }^{h}$ Oceanodroma melania

Order PASSERIFORMES

Family Tyrannidae

Subfamily Pipromorphinae

*cMionectes striaticollis

* Mionectes olivaceus

"Mionectes oleagineus

'Leptopogon superciliaris

'Todirostrum cinereum

Subfamily Tyranninae

*chyllomyias griseiceps

"Zimmerius chrysops

'Camptostoma obsoletum

'Phaeomyias murina

${ }^{*}$ Capsiempis flaveola

'Myiopagis subplacens

'Pseudelaenia leucospodia

* Elaenia flavogaster

${ }^{2}$ Elaenia albiceps

"Mecocerculus calopterus

'Euscarthmus meloryphus

*tLophotriccus pileatus

'Tolmomyias sulphurescens

pPlatyrinchus mystaceus

"Onychorhynchus coronatus

* Myiophobus flavicans

'Myiophobus fasciatus

* Myiobius barbatus

Myiobius atricaudus

† Lathrotriccus griseipectus

${ }^{\text {bd }}$ Contopus fumigatus

* $\xi$ Contopus sordidulus

'Contopus cinereus

* Sayornis nigricans

tPyrocephalus rubinus

'Ochthoeca salvini

'Muscigralla brevicauda

'Fluvicola nengeta

$\mathrm{t}^{\mathrm{p}}$ Attila torridus

'Myiarchus semirufus

*bt Myiarchus tuberculifer

'Myiarchus phaeocephalus

'Tyrannus niveigularis

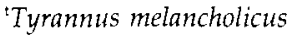

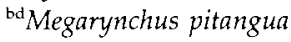

* Myiodynastes chrysocephalus

'Myiodynastes bairdii

'Myiodynastes maculatus

* Myiozetetes cayanensis

${ }^{1}$ Myiozetetes similis

'Myiozetetes granadensis
Buller's Shearwater

Sooty Shearwater

Waved Albatross

White-vented Storm-petrel

Black Storm-petrel

Streak-necked Flycatcher Olive-striped Flycatcher

Ochre-bellied Flycatcher

Slaty-capped Flycatcher

Common Tody-flycatcher

Sooty-headed Tyrannulet

Golden-faced Tyrannulet

Southern Beardless-tyrannulet

Mouse-coloured Tyrannulet

Yellow Tyrannulet

Pacific Elaenia

Grey-and-white Tyrannulet

Yellow-bellied Elaenia

White-crested Elaenia

Rufous-winged Tyrannulet

Tawny-crowned Pygmy-tyrant

Scale-crested Pygmy-tyrant

Yellow-olive Flycatcher

White-throated Spadebill

Royal Flycatcher

Flavescent Flycatcher

Bran-coloured Flycatcher

Sulphur-rumped Flycatcher

Black-tailed Flycatcher

Grey-breasted Flycatcher

Smoke-coloured Pewee

Western Wood-pewee

Tropical Pewee

Black Phoebe

Vermilion Flycatcher

Tumbes Tyrant

Short-tailed Field-tyrant

Masked Water-tyrant

Ochraceous Attila

Rufous Flycatcher

Dusky-capped Flycatcher

Sooty-crowned Flycatcher

Snowy-throated Kingbird

Tropical Kingbird

Boat-billed Flycatcher

Golden-crowned Flycatcher

Baird's Flycatcher

Streaked Flycatcher

Rusty-margined Flycatcher

Social Flycatcher

Grey-capped Flycatcher 
*bt Legatus leucophaius

Tribe Schiffornithini

${ }^{*}$ Schiffornis turdinus

Tribe Tityrini

* Pachyramphus cinnamomeus

'Pachyramphus albogriseus

$\ddagger^{t}$ Pachyramphus spodiurus

'Pachyramphus homochrous

Subfamily Cotinginae

$f^{t}$ Phytotoma raimondii

* Ampelioides tschudii

Subfamily Piprinae

* Masius chrysopterus

"Manacus manacus

Family Thamnophilidae

'Taraba major

'Sakesphorus bernardi

"Thamnophilus zarumae

* Thamnophilus unicolor

*'Thamnophilus atrinucha

* Thamnistes anabatinus

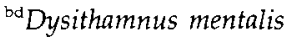

*t Thamnomanes caesius

* Myrmotherula fulviventris

* Myrmotherula schisticolor

*cercomacra nigricans

"Pyriglena leuconota

* Myrmeciza immaculata

†"Myrmeciza griseiceps

${ }^{*}$ Gymnopithys bicolor

Family Furnariidae

Subfamily Furnariinae

${ }^{\mathrm{bg}}$ Geositta peruviana

'Furnarius leucopus

"Synallaxis azarae

"Synallaxis brachyura

‡'Synallaxis tithys

'Synallaxis stictothorax

${ }^{*}$ Cranioleuca antisiensis

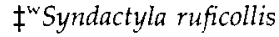

* Anabacerthia variegaticeps

* Automolus rubiginosus

‡"Hylocryptus erythrocephalus

PXenops minutus

${ }^{\text {bd Xenops rutilans }}$

Subfamily Dendrocolaptinae

${ }^{w}$ Dendrocincla fuliginosa

${ }^{t}$ Sittasomus griseicapillus

${ }^{\mathrm{X}}$ Xiphocolaptes promeropirhynchus

'Lepidocolaptes souleyetii

*Lepidocolaptes affinis

${ }^{t}$ Campylorhamphus trochilirostris

Family Formicariidae

*bt Grallaria guatimalensis

bd Grallaria watkinsi

Family Rhinocryptidae

${ }^{w}$ Melanopareia elegans
Piratic Flycatcher

Thrush-like Schiffornis

Cinnamon Becard

Black-and-white Becard

Slaty Becard

One-coloured Becard

Peruvian Plantcutter

Scaled Fruiteater

Golden-winged Manakin

White-bearded Manakin

Great Antshrike

Collared Antshrike

Chapman's Antshrike

Uniform Antshrike

Western Slaty-antshrike

Russet Antshrike

Plain Antvireo

Cinereous Antshrike

Checker-throated Antwren

Slaty Antwren

Jet Antbird

White-backed Fire-eye

Immaculate Antbird

Grey-headed Antbird

Bicoloured Antbird

Coastal Miner

Pale-legged Hornero

Azara's Spinetail

Slaty Spinetail

Blackish-headed Spinetail

Necklaced Spinetail

Line-cheeked Spinetail

Rufous-necked Foliage-gleaner

Scaly-throated Foliage-gleaner

Ruddy Foliage-gleaner

Henna-hooded Foliage-gleaner

Plain Xenops

Streaked Xenops

Plain-brown Woodcreeper

Olivaceous Woodcreeper

Strong-billed Woodcreeper

Streak-headed Woodcreeper

Spot-crowned Woodcreeper

Red-billed Scythebill

Scaled Antpitta

Scrub Antpitta

Elegant Crescent-chest 
Family Vireonidae

'Cyclarhis guianensis

bd Vireo olivaceus

* Vireo leucophrys

"Hylophilus decurtatus

Family Corvidae

Subfamily Corvinae

Tribe Corvini

'Cyanocorax mystacalis

Family Muscicapidae

Subfamily Turdinae

* Myadestes ralloides

*Catharus fuscater

${ }^{*}$ Catharus dryas

$\S^{\mathrm{P}}$ Catharus ustulatus

'Turdus reevei

"Turdus maculirostris

Family Sturnidae

Tribe Mimini

'Mimus longicaudatus

Family Certhiidae

Subfamily Troglodytinae

${ }^{t}$ Campylorhynchus fasciatus

* Thryothorus mystacalis

${ }^{b d}$ Thryothorus sclateri

${ }^{*}$ Thryothorus nigricapillus

'Thryothorus superciliaris

'Troglodytes aedon

"Henicorhina leucophrys

Subfamily Polioptilinae

* Microbates cinereiventris

"Ramphocaenus melanurus

'Polioptila plumbea

Family Hirundinidae

Subfamily Hirundininae

sTachycineta albilinea

'Phaeoprogne tapera

"Progne chalybea

'Progne modesta

* Notiochelidon cyanoleuca

'Stelgidopteryx ruficollis

$\S$ Riparia riparia

$\S^{t}$ Hirundo rustica

$\S^{\text {s Hirundo pyrrhonota }}$

${ }^{\text {s Hirundo rufocollaris }}$

Family Fringillidae

Subfamily Fringillinae

Tribe Carduelini

*cCarduelis magellanica

$t^{t}$ Carduelis siemiradzkii

Subfamily Emberizinae

Tribe Emberizini

*'Zonotrichia capensis

'Aimophila stolzmanni

*t Arremon aurantiirostris

${ }^{t}$ Arremon abeillei
Rufous-browed Peppershrike

Red-eyed Vireo

Brown-capped Vireo

Lesser Greenlet

White-tailed Jay

Andean Solitaire

Slaty-backed Nightingale-thrush

Spotted Nightingale-thrush

Swainson's Thrush

Plumbeous-backed Thrush

Ecuadorian Thrush

Long-tailed Mockingbird

Fasciated Wren

Whiskered Wren

Speckle-breasted Wren

Bay Wren

Superciliated Wren

House Wren

Grey-breasted Wood-wren

Tawny-faced Gnatwren

Long-billed Gnatwren

Tropical Gnatcatcher

Mangrove Swallow

Brown-chested Martin

Grey-breasted Martin

Southern Martin

Blue-and-white Swallow

Southern Rough-winged

Swallow

Sand Martin

Barn Swallow

Cliff Swallow

Chestnut-collared Swallow

Hooded Siskin

Saffron Siskin

Rufous-collared Sparrow

Tumbes Sparrow

Orange-billed Sparrow

Black-capped Sparrow 
${ }^{\mathrm{P}}$ Arremonops conirostris

* Atlapetes rufinucha

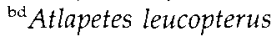

†"Atlapetes albiceps

* Atlapetes brunneinucha

"Atlapetes torquatus

Tribe Parulini

'Parula pitiayumi

'Dendroica petechia

${ }^{t} G$ eothlypis aequinoctialis

"Myioborus miniatus

bd Basileuterus fraseri

"Basileuterus trifasciatus

* Basileuterus fulvicauda

Tribe Thraupini

"Coereba flaveola

'Schistochlamys melanopis

${ }^{\mathrm{P} C o n o t h r a u p i s ~ s p e c u l i g e r a}$

*bt Chlorospingus ophthalmicus

"Chlorospingus canigularis

${ }^{1}$ Hemithraupis guira

PTachyphonus luctuosus

'Piranga flava

*t Ramphocelus flammigerus

'Thraupis episcopus

* Thraupis palmarum

* Anisognathus somptuosus

PPipraeidea melanonota

${ }^{t}$ Euphonia saturata

${ }^{t}$ Euphonia laniirostris

"Euphonia xanthogaster

* Tangara arthus

* Tangara icterocephala

"Tangara gyrola

*bt Tangara ruficervix

* Tangara cyanicollis

*cTangara nigroviridis

* Tangara viridicollis

*tChlorophanes spiza

* Tersina viridis

'Rhodospingus cruentus

'Phrygilus plebejus

'Piezorhina cinerea

'Poospiza hispaniolensis

'Sicalis flaveola

'Sicalis taczanowskii

* Volatinia jacarina

"Sporophila americana

*bt Sporophila luctuosa

"Sporophila nigricollis

'Sporophila peruviana

'Sporophila telasco

"Tiaris obscura

Tribe Cardinalini

'Pheucticus chrysogaster

"Saltator maximus

'Saltator albicollis
Black-striped Sparrow

Rufous-naped Brush-finch

White-winged Brush-finch

White-headed Brush-finch

Chestnut-capped Brush-finch

Stripe-headed Brush-finch

Tropical Parula

Yellow Warbler

Masked Yellowthroat

Slate-throated Redstart

Grey-and-gold Warbler

Three-banded Warbler

Buff-rumped Warbler

Bananaquit

Black-faced Tanager

Black-and-white Tanager

Common Bush-tanager

Ashy-throated Bush-tanager

Guira Tanager

White-shouldered Tanager

Hepatic Tanager

Flame-rumped Tanager

Blue-grey Tanager

Palm Tanager

Blue-winged Mountain-tanager

Fawn-breasted Tanager

Orange-crowned Euphonia

Thick-billed Euphonia

Orange-bellied Euphonia

Golden Tanager

Silver-throated Tanager

Bay-headed Tanager

Golden-naped Tanager

Blue-necked Tanager

Beryl-spangled Tanager

Silver-backed Tanager

Green Honeycreeper

Swallow Tanager

Crimson Finch-tanager

Ash-breasted Sierra-finch

Cinereous Finch

Collared Warbling-finch

Saffron Finch

Sulphur-throated Finch

Blue-black Grassquit

Variable Seedeater

Black-and-white Seedeater

Yellow-bellied Seedeater

Parrot-billed Seedeater

Chestnut-throated Seedeater

Dull-coloured Grassquit

Golden-bellied Grosbeak

Buff-throated Saltator

Streaked Saltator 
"Cyanocompsa cyanoides

Tribe Icterini

* Psarocolius angustifrons

${ }^{\text {tCacicus cela }}$

'Amblycercus holosericeus

'Icterus mesomelas

'Icterus graceannae

'Sturnella bellicosa

'Dives warszewiczi

${ }^{t} Q$ uiscalus mexicanus

'Molothrus bonariensis

'Scaphidura oryzivora
Blue-black Grosbeak

Russet-backed Oropendola Yellow-rumped Cacique

Yellow-billed Cacique

Yellow-tailed Oriole

White-edged Oriole

Peruvian Meadowlark

Scrub Blackbird

Great-tailed Grackle

Shiny Cowbird

Giant Cowbird 